\title{
Effect of plant growth regulators and antioxidants on in vitro plant regeneration and callus induction from leaf explants of purple passion fruit (Passiflora edulis Sims)
}

\author{
Yoon Sun Huh $\cdot$ Joung Kwan Lee $\cdot$ Sang Young Nam \\ Received: 21 August 2017 / Revised: 27 September 2017 / Accepted: 28 September 2017 \\ (c) Korean Society for Plant Biotechnology
}

\begin{abstract}
Purple passion fruit (Passiflora edulis Sims) is one of the introduced tropical plants, an increasing interest has arisen due to its distinctive taste and attractive flavor. It is expected that passion fruit production and planted area will increase gradually in the years ahead because of high profitability and consumer's demands of healthful ingredients. So we tried to investigate the effect of plant growth regulators and antioxidants on in vitro plant regeneration and callus induction from leaf explants of passion fruit for an establishment of optimal mass propagation system. Young leaf explants of purple passion fruit were cultured in Murashige and Skoog (MS) medium containing different growth regulators and antioxidant additives to induce the shoot organogenesis. After 8 weeks, the highest embryogenic callus formation rate was obtained in MS medium supplemented with $1 \mathrm{mg} \cdot \mathrm{L}^{-1}$ 6-benzylaminopurine (BAP) and $2 \mathrm{mg} \cdot \mathrm{L}^{-1}$ 2,4-dichlorophenoxyacetic acid (2,4-D), furthermore, the shoot development via organogenesis was also observed. Silver nitrate $\left(\mathrm{AgNO}_{3}\right)$, which was added into the medium to minimize the adverse effects of leached phenolics, was effective for reduction of medium browning and sudden explant death. In the medium supplemented with $1 \mathrm{mg} \cdot \mathrm{L}^{-1} \mathrm{BAP}$ and $1 \mathrm{mg} \cdot \mathrm{L}^{-1}$ gibberellic acid $\left(\mathrm{GA}_{3}\right)$, shoots were most vigorously regenerated and elongated. Most shoots rooted successfully in half strength medium with $1 \mathrm{mg} \cdot \mathrm{L}^{-1}$ indol-3 acetic acid (IAA), and more than $90 \%$ of plantlets survived after 4-month acclimatization period.
\end{abstract}

Keywords Passiflora, Plant growth regulator, Silver nitrate, In vitro propagation, Organogenesis, Plant regeneration

Y. S. Huh $(\varangle) \cdot$ J. K. Lee $\cdot$ S. Y. Nam

Horticultural Research Division, Chungcheongbuk-do Agricultural Research and Extension Services, Cheongju, 28130, Korea e-mail: yshuh2@korea.kr

\section{Introduction}

The genus Passiflora is one of the family Passifloraceae which consists of 24 subgenera and 465 species distributed in tropical and subtropical regions (Garcia et al. 2011). It is considered as an economically important crop because of the nutritional value of fruits, pharmaceutical properties of leaves and ornamental value of flowers. Passiflora edulis Sims, the purple passion fruit, is the most important and popular species in many countries, which are particularly valued for its edible sweet fruits and ornamental qualities. It can be propagated by seeds, cuttings, air-layering or grafting. But seedlings generate high levels of genetic variability, and the conventional propagation methods such as cutting or grafting depend on some factors including plant age, physiological condition and cultural practices. Therefore in vitro tissue culture techniques for Passiflora species can be useful for clonal propagation of superior genotypes and disease-free plants as well as breeding materials.

Several studies also reported that the plant regeneration of passion fruit could be obtained via organogenesis from a wide range of species and types of explants such as leaf, hypocotyl, root and cotyledon (Braglia et al. 2010; Fernando et al. 2007; Lombardi et al. 2007; Nhut et al. 2007; Pinto et al. 2010; Silva et al. 2011). Two morphogenic pathways are known to be related to in vitro plant differentiation and regeneration process, de novo organogenesis and somatic embryogenesis (Rochas et al. 2015). The most common in vitro plant development pathway is de novo organogenesis, which has the monopolar structure formation, either shoot meristems or root meristems are formed from cultured explants. On the other hand, somatic embryogenesis shows a bipolar structure formation, in which shoot and root meristems are differentiated simultaneously at opposite poles. It is an artificial process in which a plant or embryo is derived from 
a single somatic cell or group of somatic cells. Somatic embryos are formed from plant cells that are not normally involved in the development of embryos, i.e. ordinary plant tissue. These morphogenic pathways can be dependent on the balance of plant growth regulator (PGR) and tissue culture conditions (De Klerk et al. 1997; Fehér et al. 2003).

Here we aimed to investigate the effect of plant growth regulators and antioxidants on in vitro plant regeneration and callus induction from leaf explants of purple passion fruit, and compare the respective morphogenic responses in order to find the optimal mass propagation methods amenable to large-scale vegetative production system.

\section{Materials and Methods}

Plant materials

In May and June, young leaves were obtained from 1-year old grafted nursery trees in a greenhouse of Chungcheongbuk-do Agricultural Research and Extension Services. The apical expanded leaves were washed briefly, and sterilized with $2 \%(\mathrm{v} / \mathrm{v})$ sodium hypochlorite solution and $0.1 \%(\mathrm{v} / \mathrm{v})$ Tween-20 for $12 \sim 15 \mathrm{~min}$, followed by three rinses in sterile distilled water. The explants were taken from the central part of leaves, which contained the midvein, and cut into the discs (approximately $12 \sim 13 \mathrm{~mm}$ in diameter). These leaf explants were individually placed abaxial side up in the plant culture dish $(\Phi 100 \mathrm{x} \mathrm{h40} \mathrm{mm).}$

Effect of plant growth regulators on in vitro plant regeneration and callus induction from leaf explants of purple passion fruit

The callus induction medium was Murashige and Skoog (MS) medium (Murashige and Skoog, 1962) including B5 vitamins with $\operatorname{BAP}\left(0,0.5,1\right.$ and $\left.2 \mathrm{mg} \cdot \mathrm{L}^{-1}\right)$ and 2,4-D $(0,1,2$ and $\left.4 \mathrm{mg} \cdot \mathrm{L}^{-1}\right)$. This each medium was supplemented with 30 $\mathrm{g} \cdot \mathrm{L}^{-1}$ sucrose, $100 \mathrm{mg} \cdot \mathrm{L}^{-1}$ myo-inositol and $8 \mathrm{~g} \cdot \mathrm{L}^{-1}$ agar. The $\mathrm{pH}$ was adjusted to 5.8 before autoclaving (at $121^{\circ} \mathrm{C}$ and $1.2 \mathrm{kgf} \cdot \mathrm{cm}^{-2}$ pressure for $\left.15 \mathrm{~min}\right) .100 \mathrm{ml}$ of medium was poured onto each plant culture dish $(\Phi 100 \times \mathrm{h} 40 \mathrm{~mm})$. This experiment was designed randomly. Each treatment had six replicates and was conducted three times. Leaf explants were individually placed into the plant culture dish, and they were incubated in darkness at $23 \pm 1^{\circ} \mathrm{C}$ during 2 weeks at the beginning of culture, and kept under $23 \pm$ $1^{\circ} \mathrm{C}$ and $16 \mathrm{~h}$ photoperiod $\left(40 \mu \mathrm{mol} \cdot \mathrm{m}^{-2} \cdot \mathrm{s}^{-1}\right.$ light intensity) for 4 weeks. The rates of callus formation, somatic embryo like tissue induction and shoot development were counted after 6 weeks of culture.

For rapid plant regeneration and vigorous shoot elongation, explants were transferred into the MS medium including $\mathrm{B} 5$ vitamins with $\mathrm{BAP}\left(0,0.5,1\right.$ and $\left.2 \mathrm{mg} \cdot \mathrm{L}^{-1}\right)$ and $\mathrm{GA}_{3}$ $\left(0,0.5,1\right.$ and $\left.2 \mathrm{mg} \cdot \mathrm{L}^{-1}\right)$. This each medium was supplemented with $30 \mathrm{~g} \cdot \mathrm{L}^{-1}$ sucrose, $100 \mathrm{mg} \cdot \mathrm{L}^{-1}$ myo-inositol and $8 \mathrm{~g} \cdot \mathrm{L}^{-1}$ agar. The $\mathrm{pH}$ was adjusted to 5.8 before autoclaving (at $121^{\circ} \mathrm{C}$ and $1.2 \mathrm{kgf} \cdot \mathrm{cm}^{-2}$ pressure for $15 \mathrm{~min}$ ). $100 \mathrm{ml}$ of medium was poured onto $450 \mathrm{ml}$ glass culture vessel. This experiment was designed randomly. Each treatment had six replicates and was conducted three times. Explants were incubated under $23 \pm 1{ }^{\circ} \mathrm{C}$ and $16 \mathrm{~h}$ photoperiod $\left(40 \mu \cdot \mathrm{mol} \cdot \mathrm{m}^{-2} \cdot \mathrm{s}^{-1}\right.$ light intensity) for 4 weeks, and then, they were newly subcultured into the each medium. After 4 weeks of culture, their growth characteristics including shoot number, length and survival rate were calculated.

The elongated shoots $(5 \mathrm{~cm}$ high) were transferred to rooting medium, which was half strength MS medium supplemented with IAA $\left(0,0.5,1,2\right.$ and $\left.3 \mathrm{mg} \cdot \mathrm{L}^{-1}\right), 15$ $\mathrm{g} \cdot \mathrm{L}^{-1}$ sucrose and $8 \mathrm{~g} \cdot \mathrm{L}^{-1}$ agar. And they were cultured under $23 \pm 1{ }^{\circ} \mathrm{C}$ and $16 \mathrm{~h}$ photoperiod $\left(40 \mu \cdot \mathrm{mol} \cdot \mathrm{m}^{-2} \cdot \mathrm{s}^{-1}\right.$ light intensity). After 4 weeks, their rooting percentage and survival rate were calculated.

Rooted plants were taken out of the culture vessels and washed several times with distilled water to remove traces of medium on root surfaces. Then, they were transferred to pots with a mixture of common horticultural substrates and perlite (1:1), and placed in the glasshouse for acclimatization. During 4-month acclimatization and hardening phase, the general plant growth characteristics and survival rate were recorded periodically.

Effect of antioxidants and adsorbents on in vitro plant regeneration and tissue browning of purple passion fruit

To reduce the negative effect of leached phonolics on explant regeneration and induce the vigorous shoot growth, several antioxidants (ascorbic acid and silver nitrate) and adsorbents (activated charcoal and polyvinylpyrrolidone) were tested. Ascorbic acid $\left(100 \mathrm{mg} \cdot \mathrm{L}^{-1}\right)$, silver nitrate $\left(\mathrm{AgNO}_{3}, 2 \mathrm{mg} \cdot \mathrm{L}^{-1}\right)$, activated charcoal $\left(1 \mathrm{~g} \cdot \mathrm{L}^{-1}\right)$ and polyvinylpyrrolidone (PVP, $\left.1 \mathrm{~g} \cdot \mathrm{L}^{-1}\right)$ were respectively added into the callus induction and plant regeneration medium. The $\mathrm{pH}$ was adjusted to 5.8 before autoclaving (at $121^{\circ} \mathrm{C}$ and $1.2 \mathrm{kgf} \cdot \mathrm{cm}^{-2}$ pressure for $15 \mathrm{~min}$ ). This experiment was designed randomly. Each treatment had six replicates and was conducted three times. 
Statistical analysis

Data from each experiment were subjected to Duncan's multiple range test using SAS program (Version 6.21, SAS Institute Inc., Cary, NC, USA).

\section{Results and Discussion}

Effect of plant growth regulator on in vitro plant regeneration and callus induction from leaf explants of purple passion fruit

Table 1 showed the effect of two plant growth regulators, BAP and 2,4-D, on in vitro organogenesis from culture of leaf explants of purple passion fruit during early culture stage. After 6 weeks of culture, the highest callus formation rate $(84.6 \%)$, somatic embryo like tissue induction rate $(88.2 \%)$ and survival rate $(85.1 \%)$ were obtained from MS medium supplemented with $1 \mathrm{mg} \cdot \mathrm{L}^{-1} \mathrm{BAP}$ and $2 \mathrm{mg} \cdot \mathrm{L}^{-1}$ 2,4-D after 6 weeks. Leaf segments with the adaxial surface in contact with this medium gave rise to pale green or yellowish compact calluses with friable regions at the wounded surface (Fig. 1). Plant regeneration via organogenesis was also observed from the wound surfaces and midvein of leaf segments cultured in the presence of light with the adaxial surface in contact with the medium containing 1 $\mathrm{mg} \cdot \mathrm{L}^{-1} \mathrm{BAP}$ and $2 \mathrm{mg} \cdot \mathrm{L}^{-1} 2,4-\mathrm{D}$, at frequency of $48.9 \%$. Auxins and cytokinins are the main PGRs involved in the regulation of plant cell differentiation, and their ratio is very critical for the specification of cell identity during early stages of morphogenesis (Fehér et al. 2003; Gaj 2004; Jiménez

Table 1 Effect of BAP and 2,4-D on in vitro callus formation, somatic embryo like tissue induction and shoot formation from leaf explants of purple passion fruit after 6 weeks of culture

\begin{tabular}{|c|c|c|c|c|c|}
\hline $\begin{array}{c}\text { BAP } \\
\left(\mathrm{mg} \cdot \mathrm{L}^{-1}\right)\end{array}$ & $\begin{array}{c}2,4-\mathrm{D} \\
\left(\mathrm{mg} \cdot \mathrm{L}^{-1}\right)\end{array}$ & $\begin{array}{l}\text { Callus } \\
\text { formation } \\
(\%)\end{array}$ & $\begin{array}{c}\text { Somatic embryo } \\
\text { like tissue induction } \\
(\%)\end{array}$ & $\begin{array}{c}\text { Shoot } \\
\text { formation } \\
(\%)\end{array}$ & $\begin{array}{l}\text { Survival } \\
\text { rate } \\
(\%)\end{array}$ \\
\hline 0.0 & 0.0 & $12.4 \mathrm{f}^{\mathrm{z}}$ & $3.5 \mathrm{~g}$ & $0.0 \mathrm{~g}$ & $8.8 \mathrm{f}$ \\
\hline 0.5 & 0.0 & $52.6 \mathrm{e}$ & $46.4 \mathrm{f}$ & $5.5 \mathrm{f}$ & $56.4 \mathrm{e}$ \\
\hline 0.5 & 1.0 & $64.9 \mathrm{c}$ & $54.0 \mathrm{e}$ & $16.4 \mathrm{e}$ & $69.5 \mathrm{c}$ \\
\hline 0.5 & 2.0 & $69.8 \mathrm{bc}$ & $65.5 \mathrm{c}$ & $25.6 \mathrm{~d}$ & $72.0 \mathrm{c}$ \\
\hline 0.5 & 4.0 & $59.7 \mathrm{~d}$ & $62.4 \mathrm{~cd}$ & $14.9 \mathrm{e}$ & $70.5 \mathrm{c}$ \\
\hline 1.0 & 0.0 & $70.8 \mathrm{bc}$ & $59.7 \mathrm{~d}$ & $24.2 \mathrm{~d}$ & $75.1 \mathrm{~b}$ \\
\hline 1.0 & 1.0 & $76.2 \mathrm{~b}$ & $72.9 \mathrm{~b}$ & $32.4 \mathrm{c}$ & $82.4 \mathrm{a}$ \\
\hline 1.0 & 2.0 & $84.6 \mathrm{a}$ & 88.2 a & $48.9 \mathrm{a}$ & $85.1 \mathrm{a}$ \\
\hline 1.0 & 4.0 & $68.9 \mathrm{bc}$ & $63.1 \mathrm{~cd}$ & $30.9 \mathrm{c}$ & $75.3 \mathrm{~b}$ \\
\hline 2.0 & 0.0 & $75.1 \mathrm{~b}$ & $60.6 \mathrm{~d}$ & $35.4 \mathrm{bc}$ & $71.7 \mathrm{c}$ \\
\hline 2.0 & 1.0 & $71.1 \mathrm{bc}$ & $66.4 \mathrm{c}$ & $44.8 \mathrm{ab}$ & $79.2 \mathrm{ab}$ \\
\hline 2.0 & 2.0 & $61.3 \mathrm{~d}$ & $62.5 \mathrm{~cd}$ & $50.1 \mathrm{a}$ & $75.6 \mathrm{~b}$ \\
\hline 2.0 & 4.0 & $60.9 \mathrm{~d}$ & $52.0 \mathrm{e}$ & $39.7 \mathrm{~b}$ & $65.2 \mathrm{~d}$ \\
\hline
\end{tabular}

${ }^{\mathrm{z}}$ Means followed by the same letter within columns are not significantly different at the $5 \%$ level of significant using Duncan's multiple test
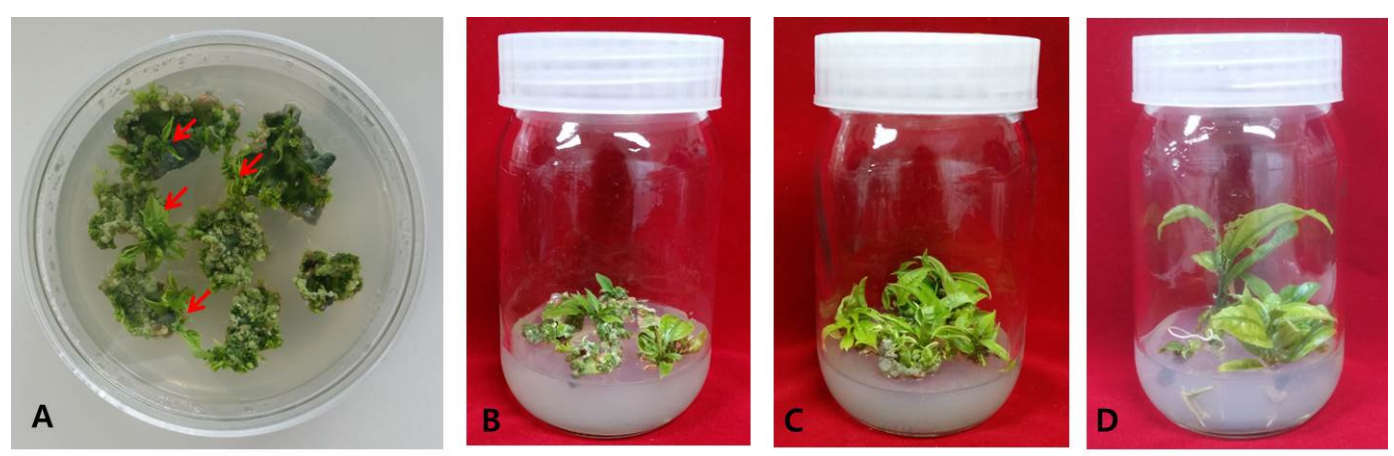

Fig. 1 In vitro organogenesis from culture of leaf explants of purple passion fruit. (A) Somatic embryo like tissues were derived from compact calluses, and shoots (arrows) were developed from the midvein of leaf segment cultured with the adaxial surface in contact with the medium supplemented with $1 \mathrm{mg} \cdot \mathrm{L}^{-1}$ BAP and with $2 \mathrm{mg} \cdot \mathrm{L}^{-1}$ 2,4-D after 6 weeks. (B) Plants were regenerated in the medium supplemented with $1 \mathrm{mg} \cdot \mathrm{L}^{-1} \mathrm{BAP}$ and with $1 \mathrm{mg} \cdot \mathrm{L}^{-1} \mathrm{GA}_{3}$ via somatic embryogenesis after 10 weeks. (C) Newly subcultured plants were proliferated and elongated after 14 weeks. (D) Roots were formed in the half strength medium with 1 mg $\cdot L^{-1} \mathrm{IAA}$ 
Table 2 Effect of BAP and $\mathrm{GA}_{3}$ on in vitro growth characteristics of shoots developed from leaf explants of purple passion fruit after 14 weeks of culture

\begin{tabular}{|c|c|c|c|c|c|}
\hline $\begin{array}{c}\text { BAP } \\
\left(\mathrm{mg} \cdot \mathrm{L}^{-1}\right)\end{array}$ & $\begin{array}{c}\mathrm{GA} 3 \\
\left(\mathrm{mg} \cdot \mathrm{L}^{-1}\right)\end{array}$ & $\begin{array}{c}\text { Plant regeneration } \\
(\%)\end{array}$ & $\begin{array}{l}\text { Number of shoots } \\
\text { (per explant) }\end{array}$ & $\begin{array}{c}\text { Shoot } \\
\text { length } \\
(\mathrm{cm})\end{array}$ & $\begin{array}{c}\text { Survival } \\
\text { rate } \\
(\%) \\
\end{array}$ \\
\hline 0.0 & 0.0 & $0.0 \mathrm{~d}^{\mathrm{z}}$ & $0.0 \mathrm{e}$ & $0.0 \mathrm{e}$ & $0.0 \mathrm{c}$ \\
\hline 0.5 & 0.0 & $56.4 \mathrm{c}$ & $2.3 \mathrm{~d}$ & $3.0 \mathrm{~d}$ & $70.2 \mathrm{~b}$ \\
\hline 0.5 & 0.5 & 65.3.b & $2.4 \mathrm{~d}$ & $3.5 \mathrm{c}$ & $75.5 \mathrm{ab}$ \\
\hline 0.5 & 1.0 & $71.5 \mathrm{ab}$ & $2.5 \mathrm{~d}$ & $4.2 \mathrm{bc}$ & 79.4 a \\
\hline 0.5 & 2.0 & $70.1 \mathrm{ab}$ & $3.0 \mathrm{c}$ & $4.8 \mathrm{~b}$ & $73.8 \mathrm{ab}$ \\
\hline 1.0 & 0.0 & $64.7 \mathrm{~b}$ & $2.9 \mathrm{c}$ & $3.4 \mathrm{c}$ & $74.6 \mathrm{ab}$ \\
\hline 1.0 & 0.5 & $68.8 \mathrm{ab}$ & $3.5 \mathrm{bc}$ & $4.1 \mathrm{bc}$ & 79.8 a \\
\hline 1.0 & 1.0 & $75.7 \mathrm{a}$ & $4.6 \mathrm{a}$ & $5.5 \mathrm{a}$ & $82.1 \mathrm{a}$ \\
\hline 1.0 & 2.0 & $77.3 \mathrm{a}$ & $4.0 \mathrm{~b}$ & $5.7 \mathrm{a}$ & $80.4 \mathrm{a}$ \\
\hline 2.0 & 0.0 & $69.2 \mathrm{ab}$ & $3.6 \mathrm{bc}$ & $3.4 \mathrm{c}$ & $75.3 \mathrm{ab}$ \\
\hline 2.0 & 0.5 & $76.2 \mathrm{a}$ & $4.1 \mathrm{~b}$ & $4.1 \mathrm{bc}$ & $81.0 \mathrm{a}$ \\
\hline 2.0 & 1.0 & $70.2 \mathrm{ab}$ & $4.8 \mathrm{a}$ & $4.6 \mathrm{~b}$ & $71.2 \mathrm{~b}$ \\
\hline 2.0 & 2.0 & $65.5 \mathrm{~b}$ & $4.6 \mathrm{a}$ & $4.6 \mathrm{~b}$ & $69.3 \mathrm{~b}$ \\
\hline
\end{tabular}

${ }^{\mathrm{z}}$ Means followed by the same letter within columns are not significantly different at the $5 \%$ level of significant using Duncan's multiple test

2005). Somatic embryogenesis and shoot organogenesis are particularly considered as complicated and sophisticated developmental processes, which are supposed to involve the different hormonal requirements and a series of biochemical or morphological changes (Duclercq et al. 2011; Yang and Zhang 2010). Gordon et al. (2007) also proposed that the balance between auxin and cytokinin specify the identities of shoot meristems cells from Arabidopsis calli derived from root tissues through the induction of specific gene expression patterns. Somatic embryos of $P$. edulis Sims were obtained when zygotic embryo were cultured in the medium supplemented with high 2,4-D/BAP ratio (Paim-Pinto et al. 2011). Haensch (2007) reported that an addition of 2,4-D and BAP was very critical on callus growth and the subsequent regeneration of somatic embryos in long-term cultures of Pelargonium x domesticum cv. Madame Layal. Rajabpoor (2007) reported that $1 \mathrm{mg} \cdot \mathrm{L}^{-1} \mathrm{BAP}$ and $2 \mathrm{mg} \cdot \mathrm{L}^{-1}$ 2,4-D was the best treatment for somatic embryogenesis induction of saffron. Rocha et al. (2015) mentioned that 2,4-D was very essential to induce the callus formation and somatic embryo induction as well as plant regeneration of $P$. edulis. Nodal segments cultured on the medium supplemented with BA formed green and compact calluses, and shoot development from these calluses occurred on the medium containing $13.2 \mathrm{uM} \mathrm{BA}$ after 60 days of culture with the highest regeneration efficiency (Pacheco et al. 2012).

Emergence of the first adventitious shoots via organogenesis was mostly observed at the cut surfaces of the mid nerve. This particular morphogenic response and subsequent formation of primordia on the injured zones may result from the accelerated cell division reaction caused by the incision and the contact with growth regulators in the culture medium (De Klerk et al. 1997). Some factors promoting morphogenesis or organogenesis may exist in the mid nerve and petiole of leaf, particularly, the meristematic activity of the parenchyma and epidermal cells in the mid nerve region is supposed to be critically involved (Pereira et al. 2000). Fernando et al. (2007) also reported direct organogenesis from leaf discs and indirect organogenesis from hypocotyls of $P$. edulis.

In the medium supplemented with $1 \mathrm{mg} \cdot \mathrm{L}^{-1} \mathrm{BAP}$ and $1 \mathrm{mg} \cdot \mathrm{L}^{-1}$ gibberellic acid $\left(\mathrm{GA}_{3}\right)$, shoots were most vigorously regenerated from somatic embryo like tissue and elongated well, its regeneration rate was $75.7 \%$, the number and length of shoot were respectively 4.6/explant and $5.5 \mathrm{~cm}$ (Table 2, Fig. 1). Adventitious shoot production from leaf segment has been previously observed in P. alata (Pinto et al. 2010; Rodriguez et al. 2007). The use of cytokinins for in vitro organogenesis in Passiflora species has also been reported with induction of adventitious buds in response to BAP alone or in association with NAA, TDZ or kinetin (Becerra et al. 2004; Dornelas and Vieira 1994; Hall et al 2000; Trevisan and Mendes 2005). Shoots from root explants of $P$. cincinnata and $P$. edulis grown in MS medium with 2.89 $\mathrm{uM} \mathrm{GA}_{3}$ were elongated about $2 \mathrm{~cm}$ after 10 days in culture (Silva et al. 2011). The shoot bud elongation of $P$. alata was more efficient using $2.88 \mathrm{uM} \mathrm{GA} 3$, its percentage was $35.0 \%$, on the other hand, none elongated shoots were obtained in control medium (Pinto et al. 2010).

Table 3 showed the effect of IAA on in vitro rooting of shoots developed from leaf explants of purple passion fruit after 14 weeks of culture. The highest root formation 
Table 3 Effect of IAA on in vitro rooting of shoots developed from leaf explants of purple passion fruit after 14 weeks of culture

\begin{tabular}{ccccc}
\hline $\begin{array}{c}\text { IAA } \\
\left(\mathrm{mg} \cdot \mathrm{L}^{-1}\right)\end{array}$ & $\begin{array}{c}\text { Root } \\
\text { formation } \\
(\%)\end{array}$ & $\begin{array}{c}\text { Number of roots } \\
\text { (per explant) }\end{array}$ & $\begin{array}{c}\text { Root } \\
\text { length } \\
(\mathrm{cm})\end{array}$ & $\begin{array}{c}\text { Survival } \\
\text { rate } \\
(\%)\end{array}$ \\
\hline 0 & $28.5 \mathrm{~d}^{\mathrm{z}}$ & $2.0 \mathrm{~d}$ & $1.4 \mathrm{c}$ & $60.6 \mathrm{~b}$ \\
0.5 & $59.4 \mathrm{c}$ & $4.5 \mathrm{c}$ & $2.6 \mathrm{~b}$ & $74.2 \mathrm{a}$ \\
1.0 & $82.7 \mathrm{a}$ & $6.1 \mathrm{a}$ & $3.4 \mathrm{a}$ & $77.4 \mathrm{a}$ \\
2.0 & $72.6 \mathrm{~b}$ & $5.3 \mathrm{~b}$ & $3.5 \mathrm{a}$ & $78.9 \mathrm{a}$ \\
3.0 & $70.8 \mathrm{~b}$ & $5.5 \mathrm{~b}$ & $3.5 \mathrm{a}$ & $73.3 \mathrm{a}$ \\
\hline
\end{tabular}

${ }^{\mathrm{z}}$ Means followed by the same letter within columns are not significantly different at the $5 \%$ level of significant using Duncan's multiple test

Table 4 Effect of antioxidants and adsorbents on in vitro plant regeneration and tissue browning of purple passion fruit

\begin{tabular}{lcccccc}
\hline \multirow{2}{*}{ Treatment } & $\begin{array}{c}\text { Somatic embryo like } \\
\text { tissue induction } \\
(\%)\end{array}$ & $\begin{array}{c}\text { Regeneration } \\
(\%)\end{array}$ & $\begin{array}{c}\text { Occurrence } \\
(\%)\end{array}$ & $\begin{array}{c}\text { Number } \\
\text { (per explant) }\end{array}$ & $\begin{array}{c}\text { Length } \\
(\mathrm{cm})\end{array}$ & $\begin{array}{c}\text { Death rate } \\
(\%)\end{array}$ \\
\cline { 3 - 7 } & $61.4 \mathrm{~d}^{\mathrm{z}}$ & $65.5 \mathrm{~b}$ & $68.5 \mathrm{a}$ & $3.9 \mathrm{~b}$ & $4.2 \mathrm{~b}$ & $32.6 \mathrm{a}$ \\
Non-treatment & $72.5 \mathrm{~b}$ & $74.8 \mathrm{a}$ & $26.5 \mathrm{c}$ & $4.3 \mathrm{ab}$ & $5.4 \mathrm{a}$ & $13.8 \mathrm{c}$ \\
$\mathrm{Ascorbic} \mathrm{acid}$ & $79.3 \mathrm{a}$ & $76.0 \mathrm{a}$ & $8.0 \mathrm{~d}$ & $4.7 \mathrm{a}$ & $5.2 \mathrm{a}$ & $4.5 \mathrm{~d}$ \\
$\mathrm{AgNO}_{3}$ & $66.0 \mathrm{c}$ & $70.0 \mathrm{ab}$ & $37.7 \mathrm{~b}$ & $3.8 \mathrm{~b}$ & $4.8 \mathrm{ab}$ & $21.4 \mathrm{~b}$ \\
$\mathrm{AC}^{\mathrm{y}}$ & $65.2 \mathrm{c}$ & $71.1 \mathrm{ab}$ & $32.1 \mathrm{bc}$ & $4.3 \mathrm{ab}$ & $4.7 \mathrm{ab}$ & $19.7 \mathrm{~b}$ \\
$\mathrm{PVP}^{\mathrm{x}}$ & & &
\end{tabular}

${ }^{\mathrm{z}}$ Means followed by the same letter within columns are not significantly different at the $5 \%$ level of significant using Duncan's multiple test.

$\mathrm{AgNO}_{3}$ (silver nitrate), ${ }^{\mathrm{y}} \mathrm{AC}$ (activated charcoal), ${ }^{\mathrm{x}} \mathrm{PVP}$ (polyvinylpyrrolidone)

Table 5 The growth characteristics of plants regenerated from leaf explants of purple passion fruit after 2 and 4 months of ex vitro acclimatization

\begin{tabular}{|c|c|c|c|c|c|c|}
\hline \multirow[b]{2}{*}{$\begin{array}{l}\text { Acclimatization } \\
\text { period }\end{array}$} & \multirow{2}{*}{$\begin{array}{l}\text { Plant } \\
\text { height } \\
(\mathrm{cm})\end{array}$} & \multirow{2}{*}{$\begin{array}{c}\text { Stem } \\
\text { diameter } \\
(\mathrm{mm})\end{array}$} & \multirow{2}{*}{$\begin{array}{c}\text { Survival } \\
\text { rate } \\
(\%)\end{array}$} & \multicolumn{3}{|c|}{ Leaf } \\
\hline & & & & $\begin{array}{c}\text { Number } \\
\text { (per explant) }\end{array}$ & $\begin{array}{l}\text { Length } \\
\text { (cm) }\end{array}$ & $\begin{array}{l}\text { Width } \\
(\mathrm{cm})\end{array}$ \\
\hline 2 months & $10.2 \pm 0.8^{\mathrm{z}}$ & $1.9 \pm 0.1$ & $93.3 \pm 3.7$ & $5.8 \pm 0.4$ & $4.4 \pm 0.2$ & $2.3 \pm 0.2$ \\
\hline 4 months & $33.5 \pm 2.6$ & $3.3 \pm 0.2$ & $90.7 \pm 4.0$ & $10.4 \pm 0.5$ & $8.0 \pm 0.4$ & $4.6 \pm 0.2$ \\
\hline
\end{tabular}

${ }^{\mathrm{z}}$ Each value represents the mean \pm SE.

rate $(82.7 \%)$ was gained when shoots were cultured in the medium with $1 \mathrm{mg} \cdot \mathrm{L}^{-1} \mathrm{IAA}$, in which their root number and length were respectively $6.1 /$ explant and $3.4 \mathrm{~cm}$. Auxins are one of the main plant hormones that play a key role in the creation of initial root growth. In particular, IAA is known to be involved in every aspect of plant growth and development, including the formation of embryo development, induction of cell division, stem elongation, vascular tissue differentiation, fruit and flower development, tropic behaviors (leaves and stems moving toward the light source) and the induction of rooting. In the culture of several Passiflora species, rooting of juvenile shoots initiated in the MS medium supplemented with 5 uM IAA (Drew 1991). Kawata et al. (1995) also reported that rooting was achieved on IAA supplemented or hormone-free medium.

After 2 and 4 months of ex vitro acclimatization, the general growth characteristics of plants derived from leaf explants of purple passion fruit were surveyed (Table 5). During this period, regenerated plants were normally grown and their survival rate was over $90 \%$. After 4 months, plant height was averagely $33.5 \mathrm{~cm}$ and leaf number was 10.4/plant (Fig. 3).

From these results, it was suggested that an addition of appropriate plant growth regulators could efficiently induce the shoot organogenesis from in vitro culture of leaf explants of passion fruit, and the optimal medium composition might be applied for an establishment of mass propagation system.

Effect of antioxidants and adsorbents on in vitro plant regeneration and tissue browning of purple passion fruit

Table 4 showed the effect of antioxidants and adsorbents on in vitro plant regeneration and tissue browning of purple passion fruit. The addition of $\mathrm{AgNO}_{3}$ was most efficient for 


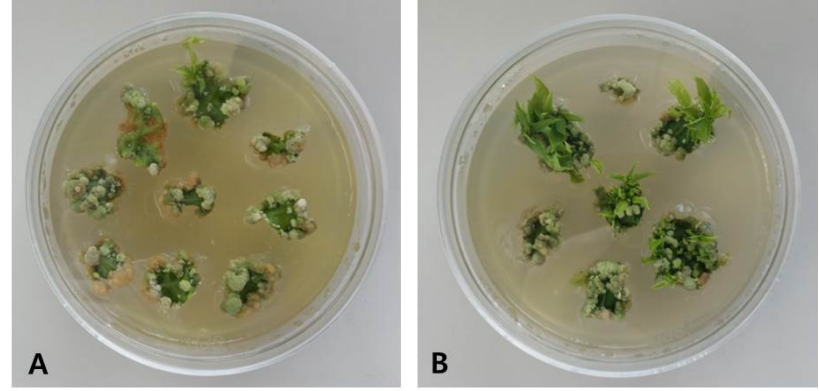

Fig. 2 Browning inhibition in in vitro culture of leaf explants with the addition of $\mathrm{AgNO}_{3}$. (A) Explants and medium turned brown in the non-added medium. (B) Browning occurrence due to the leaching of phenolics from explants was reduced and plant regeneration was improved in the medium supplemented with $\mathrm{AgNO}_{3}$

somatic embryo like tissue induction and plant regeneration, in comparison with other treatments such as ascorbic acid, activated charcoal and PVP. Particularly, the browning rate of explant tissue decreased most significantly, it was $8 \%$ in the medium with $\mathrm{AgNO}_{3}$, compared with non-treatment (68.5\%). Shoots were also grown most vigorously in $\mathrm{AgNO}_{3}$ containing medium. Figure 2 also explained the browning inhibition of in vitro leaf explants cultured in $\mathrm{AgNO}_{3}$ supplemented medium.

There are two main direct reasons for browning in the process of plant tissue culture. The first reason is programmed cell death caused by environmental stress or natural necrosis, the other reason is the formation of quinones from phenolic compounds in plant cell under the effect of polyphenol oxidase (Gao 1999). Many phenolic substances exist in the tissue explants, their oxidation reaction may happen under an appropriate conditions such as $\mathrm{pH}$, temperature and polyphenol oxidase, and then poisonous substances (lignin, tannins or pigments) may be also produced and the incisions of explants quickly turn brown or black at last (Zhang et al. 2004; Zhou et al. 2000). If these oxidized phenolic compounds such as quinones spread into medium and continue to be accumulated, they would suppress the activity of other enzymes and poison the explants, the culture medium would be also polluted (Arnaldos et al. 2001; Rathore et al. 1991). Therefore it is very important to minimize the lethal browning or blackening of explants caused by phenolic compounds during plant tissue culture. These include treating explants with polyphenol adsorbents such as activated charcoal and PVP, or with antioxidants such as cysteine, ascorbic acid and silver nitrate into the culture medium (Arditti and Ernst. 1993; Lainé and David 1994; Sanyal et al. 2005).

Nowadays silver nitrate has been used widely as an efficient antioxidant for overcoming explant browning in a

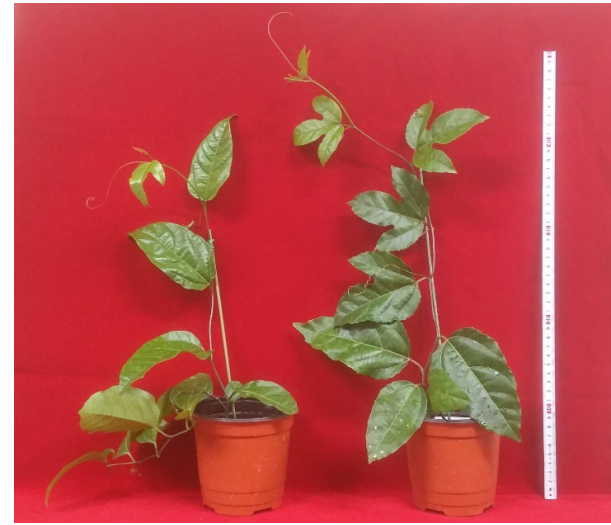

Fig. 3 Acclimatized regenerated plants after 4 months of transfer from in vitro culture

various culture process. Silver nitrate is considered as a potential inhibitor of ethylene activity and plant growth modulator (Kumar et al. 2009). It has several properties such as easy availability, solubility in water, specificity and stability, which can make it very useful and powerful for various applications in exploiting plant growth regulation and morphogenesis in vivo and in vitro. Silver ions in the form of nitrate, such as $\mathrm{AgNO}_{3}$, play a major role in influencing somatic embryogenesis, shoot formation and efficient root formation. Particularly, it is capable of specifically blocking the action of exogenously applied ethylene in classical responses such as abscission, senescence and growth retardation (Bais et al. 1999; Bais et al. 2000a; Bais et al. 2000b; Bais et al. 2001a; Bais et al. 2001b; Bais et al. 2001; Beyer 1976).

Passiflora species are generally considered to produce ethylene at high rates, and the tissue culture medium supplementation with ethylene action inhibitors has proved to improve the bud formation and enhance shoot growth as well as differentiation (Faria and Segura 1997; Trevisan and Mendes 2005). Pinto et al. (2010) reported that in vitro organogenesis induction of sweet passion fruit occurred more efficiently when hypocotyl segment-derived explants were cultured in MS medium supplemented with BAP and $\mathrm{AgNO}_{3}$ under 16-h photoperiod. Trevisan et al. (2005) also reported that the bud induction and shoot development of P. edulis Sims. F. flavicarpa was enhanced TDZ and $\mathrm{AgNO}_{3}-$ supplemented media.

Our results demonstrated that the rapid and reproducible in vitro plant regeneration derived from organogenesis of leaf explants could be obtained efficiently by supplementing an proper antioxidant into culture medium in order to reduce the negative effect of leached phenolics on explant regeneration. 


\section{References}

Arditti J, Ernst R (1993) Micropropagation of orchids. John Wiley $\&$ Sons, New York

Arnaldos TL, Munoz R, Ferrer MA, Calderon AA (2001). Changes in phenol content during strawberry (Fragaria $x$ ananasa, $\mathrm{cv}$. Chandler) callus culture. Physiol Plant. 113:315-322

Bais HP, George J, Ravishankar GA (1999) Influence of polyamines on growth of hairy root cultures of witloof chiocory (Chichorium intybus $\mathrm{L}$ cv Lucknow local) and formation of coumarins. J Plant Growth Regul. 18:33-37

Bais HP, Sudha GS, Suresh B. Ravishankar GA (2000a) $\mathrm{AgNO}_{3}$ influences in vitro root formation in Decalepis hamiltonii Wight and Arn. Current Science. 79:894-898

Bais, HP, Sudha GS, Ravishankar GA (2000b) Putrescine and $\mathrm{AgNO}_{3}$ influences shoot multiplication In vitro flowering and endogenous titers of polyamines in Chichorium intybus L. cv. Lucknow Local. J Plant Growth Regul. 19:238-248

Bais HP, Sudha GS, Ravishankar GA (2001a) Influence of putrescine $\mathrm{AgNO}_{3}$ and polyamine inhibitors on the morphogenetic response in untransformed and transformed tissues of Chichorium intybus and their regenerants. Plant Cell Reports. 20:547-555

Bais HP, Sudha GS, Ravishankar GA (2001b) Putrescine influences growth and production of coumarins in transformed and untransformed root cultures of witloof chicory (Chichorium intybus L. cv. Lucknow Local). Acta Physiologia Plantarum. 23:319-327

Bais HP, Venkatesh RT, Chandrashekar A, Ravishankar GA (2001) Agrobacterium rhizogenes-mediated transformation of Witloof chicory-in vitro shoot regeneration and induction of flowering. Current Science. 80:83-87

Becerra DC, Forero AP, Góngora GA (2004) Age and physiological condition of donor plants affect in vitro morphogenesis in leaf explants of Passiflora edulis f. flavicarpa. Plant Cell Tiss Org Cult. 79:87-90

Beyer EM (1976) Silver ion: a potent anti-ethylene agent in cucumber and tomato. HortScience. 11:175-196

Braglia L, Benedetti L, Giovannini A, Nicoletti F, Bianchini C, Pipino L, Mercuri A (2010) In vitro plant regeneration as a tool to improve ornamental characters in Passiflora species. Acta Hort. 855:47-52

De Klerk GJ, Arnholdt-Schmitt B, Lieberei R, Neumann KH (1997) Regeneration of roots, shoots and embryos: physiological, biochemical and molecular aspects. Biol Plant. 39:53-66

Dornelas MC, Vieira MLC (1994) Tissue culture studies on species of Passiflora. Plant Cell Tiss Org Cult. 36:211-217

Drew RA (1991) In vitro culture of adult and juvenile bud explants of Passiflora species. Plant Cell Tiss Organ Cult. 26:23-27

Duclercq J, Sangwan-Norreel B, Catterou M, Sangwan RS (2011) De novo shoot organogenesis: from art to science. Trends Plant Sci. 16:597-606

Faria JLC, Segura J (1997) Micropropagation of yellow passionfruit by axillary bud proliferation. Hortscience. 32:1276-1277

Fehér A, Pasternak TP, Dudits D (2003) Transition of somatic plant cells to an embryogenic state. Plant Cell Tiss Organ Cult.
74:201-228

Fernando JA, Vieira MLC, Machado SR, Appezzato-da-Gloria B (2007) New insights into the in vitro organogenesis process: the case of Passiflora. Plant Cell Tiss Organ Cult. 91:37-44

Gaj MD (2004) Factors influencing somatic embryogenesis induction and plant regeneration with particular reference to Arabidopsis thaliana (L.) Heynh. Plant Growth Regul 43:27-47.

Gao GX (1999) Browning in plant tissue culture. Plant Physiol Commun. 35:501-506

Garcia R, Pacheco G, Falcão E (2011) Influence of type of explant, plant growth regulators, salt composition of basal medium, and light on callogenesis and regeneration in Passiflora suberosa L. (Passifloraceae). Plant Cell Tiss Organ Cult. 106:47-54

Gordon SP, Heisler MG, Reddy GV, Ohno C, Das P, Meyerowitz EM (2007) Pattern formation during de novo assembly of the Arabidopsis shoot meristem. Development. 134:3539-3548

Haensch KT (2007) Influence of 2,4-D and BAP on callus growth and the subsequent regeneration of somatic embryos in long-term cultures of Pelargonium $\mathrm{x}$ domesticum cv. Madame Layal. Electronic Journal of Biotechnology. 10:1-9

Hall RM, Drew RA, Higgins CM, Dietzgen RG (2000) Efficient organogenesis of an Australian passionfruit hybrid (Passiflora edulis x Passiflora edulis var. flavicarpa) suitable for gene delivery. Aust J Bot. 48:673-680

Jiménez VM (2005) Involvement of plant hormones and plant growth regulators on in vitro somatic embryogenesis. J Plant Growth Regul. 47:91-110

Kawata K, Ushida C, Kawai F, Kanamori M, Kuriyama A (1995) Micropropagation of passion fruit from subcultured multiple shoot primordia. J Plant Physiol. 147: 281-284

Kumar V, Parvatam G, Ravishankar GA (2009) AgNO3: a potential regulator of ethylene activity and plant growth modulator. Electronic Journal of Biotechnology. 12:8-9

Lainé E, David A (1994). Regeneration of plants from leaf explants of micropropagated clonal Eucalyptus grandis. Plant Cell Rep. 13: 473-476

Lombardi SP, Passos IRS, Nogueira MCS, Appezzato-da-Glória B (2007) In vitro shoot regeneration from roots and leaf discs of Passiflora cincinnata mast. Braz Arch Biol Technol. 50: 239-247

Nhut DT, Khiet BLT, Thi NN, Thuy DTT, Duy N, Hai NT, Huyen PX (2007) High frequency shoot formation of yellow passion fruit (Passiflora edulis f. flavicarpa) via thin cell layer (TCL) Technology. In: Protocols for Micropropagation of Woody Trees and Fruits. Springer Netherlands. p. 417-426

Murashige T, Skoog F (1962) A revised medium for rapid growth and bioassays with tobacco tissue cultures. Physiol Plant. 15:473-497

Pacheco G, Garcia R, Lugato D, Vianna M, Mansur E (2012) Plant regeneration, callus induction and establishment of cell suspension cultures of Passiflora alata Curtis. Sci. Hortic. 144:42-47

Paim-Pinto DL, Almeida AMR, Rêgo MM, Silva ML, Oliveira EJ, Otoni WC (2011) Somatic embryogenesis from mature zygotic 
embryos of commercial passionfruit (Passiflora edulis Sims) genotypes. Plant Cell Tiss Organ Cult. 107:521-530

Pereira AMS, Bertoni BW, Appezzato-da-Glória B, Araujo AR, Januário AH, Lourenço MV, França SC (2000) Micropropagation of Pothomorphe umbellata via direct organogenesis from leaf explants. Plant Cell Tiss Organ Cult. 60:47-53

Pinto AP, Monteiro-Hara ACBA, Stipp LCL, Mendes BMJ (2010) In vitro organogenesis of Passiflora alata. In vitro Cell Dev Biol Plant. 46:28-33

Rathore TS, Tandon P, Shekhawat NS (1991) In vitro regeneration of Pitcher plant (Nepenthes khasiana Hook. F.)- A rare insectivorous plant of India. J Plant Physiol. 139:246-248

Rodriguez MV, Severín CR, Giubileo G, Gattuso MA, Pulido L, Di Sapio OA, Gattuso SJ (2007) Cultivo in vitro de Passiflora alata, una forma de conservacíon genética. Actas de Horticultura 48:69-72

Sanyal I, Singh AK, Kaushik M, Amla DV (2005). Agrobacterium mediated transformation of chickpea (Cicer arietinum L.) with Bacillus thuringiensis crylAc gene for resistance against pod borer insect Helicoverpa armigera. Plant Sci. 168: 1135-1146

Silva CV, Oliveira LS, Loriato VAP, Silva LC, Campos JMS, Viccini LF, Oliveira EJ, Otoni WC (2011) Organogenesis from root explants of commercial populations of Passiflora edulis Sims and a wild passionfruit species, $P$. cincinnata Masters. Plant Cell Tiss Organ Cult. 107:407-416

Trevisan F, Mendes BMJ (2005) Optimization of in vitro organogenesis in passion fruit (Passiflora edulis f. flavicarpa). Sci Agric. 62:346-350

Rajabpoor Sh, Azghandi AV, Saboora A (2007) Effects of different concentrations of 2,4-D and BAP on somatic embryogenesis induction in saffron (Crocus sativus L.). Pak J Biol Sci. 10: 3927-3930

Rocha DI, Monte-Bello CC, Dornelas MC (2015) Alternative induction of de novo shoot organogenesis or somatic embryogenesis from in vitro cultures of mature zygotic embryos of passion fruit (Passiflora edulis Sims) is modulated by the ratio between auxin and cytokinin in the medium. Plant Cell Tiss Organ Cult. 120:1087-1098

Yang X, Zhang X (2010) Regulation of somatic embryogenesis in higher plants. Crit Rev Plant Sci. 29:36-57

Zhang SH, Wang D, Wang Q (2004) Factors influencing the browning of potato mesophyll protoplasts and the effect of $\mathrm{AgNO}_{3}$ on their browning and division. China Potato J. 18:77-81

Zhou JH, Zhou JR and Zeng HS (2000) Advance of studies on browning and antibrowning techniques in the tissue culture of horticultural plants. Acta Hortic J. 27:481-486 